\title{
The Effect of Food Additives (Monosodium Glutamate - MSG) On Human Health - A Critical Review
}

\author{
Zahraa Hameed Al-Agili \\ Biochemical Engineering Department, Al-Khwarizmi College of Engineering, University of Baghdad, Iraq \\ engzahraahameed@gmail.com
}

\begin{abstract}
:
According to the famous saying of the medieval physician Paracelsus, "There is no substance without poison. Only the dose determines the extent of the toxic effect." Here, the effect of monosodium glutamate (MSG) on human health and the risks to the health of its frequent use in the short term was addressed and the long term was evaluated according to the studies of several researchers specializing in this regard. Monosodium glutamate (MSG) is known as one of the most popular food additives that classified as a flavor enhancer. Parts of the evidence were reviewed from the literature explaining its effect on immune system cells in addition to metabolic disorders by exposing individuals to obesity and what is known as metabolic syndrome, as well as reviewing a lot of evidence indicating the effect of MSG intake on the health of the kidney, liver and other parts of the body through Practical application to laboratory rats and clinical studies in humans.
\end{abstract}

Keywords: Monosodium Glutamate; MSG; E621; Food Additives; Flavor Enhancer. 


\section{INTRODUCTION}

Food additives have a special place in the food production process; on the other hand, consumers began to search for ready-to-eat food options, but with safety and health standards, so that many people became willing to spend more money to buy (biological) foods free of dangerous industrial additives $[1,2]$. Chemicals called (food additives) are defined as substances that added to food for a specific purpose, and they are either natural or industrial [3]. Food additives are classified into coloring agents, stabilizers, emulsifiers, flavorings, and preservatives [4].

In the middle of the twentieth century, the risks of using food additives were assessed globally, as a joint committee (JECFA) of experts of the World Health Organization (WHO) of the United Nations and the Food and Agriculture Organization (FAO) was established in 1955 on food additives [5]. In past decades, obesity and metabolic syndrome have been linked to foods that contain large amounts of fats and sugars a person eats, however, evidence has indicated that food additives may be the cause of a metabolic derangement [6]. Despite the efforts made to ensure the safe and proper use of food additives, the toxic genetic effects of these additives target the liver and kidneys, which increases their risk on the immune system, which is the defense system that is responsible for protecting the body from pathogenic microorganisms $[7,8]$.

In this review, Monosodium glutamate (MSG) was chosen as one of the important food additives used worldwide, as (the Food and Drug Administration - FDA) classified MSG as a food ingredient "generally recognized as safe," but it should be included on the food labels added to it because its use so far is considered a controversial source [9].

\section{CHEMISTRY OF MONOSODIUM GLUTAMATE (MSG)}

Monosodium glutamate (MSG) is a crystalline powder as shown in Figure (1) that used internationally as a flavor enhancer [10]. Crude glutamates have a meaty flavor due to the presence of contaminants in its contents. Addition to being sweet/salty in large concentrations [11]. Extensive physical, chemical and toxicological information Listed below $[12,13]$.

Chemical name: Monosodium glutamate (MSG)

CAS No.: 142-47-2 ， Molecular weight: 169.1112

Partition coefficient: -7.060 , Water solubility: $385,000 \mathrm{mg} / \mathrm{L}$ at $25^{\circ} \mathrm{C}$

Molecular formula: $\mathrm{C} 5 \mathrm{H} 8 \mathrm{NaNO} 4 . \mathrm{H} 2 \mathrm{O}$

GHS classification: Not a hazardous substance or mixture according to GHS

Synonyms: Glutamic acid, monosodium salt, Sodium glutamate, Ajinomoto, Ancoma, Chinese seasoning , E621, Glutacyl, Glutamat sodny (Czech), Glutamate Sodium (Japanese), Glutamic acid, L-, sodium salt, Glutamic acid, monosodium salt ,Glutammato monosodico (Italian), Glutavene L(+), Sodium glutamate, Monosodioglutammato [Italian], Monosodium glutamate anhydrous, Monosodium L-glutamate, MSG, Natrium Lhydrogenglutamat, Natriumglutaminat, Natriumglutaminat (German), Sodium hydrogen glutamate, Glutamic acid, monosodium salt, L. 
Toxicity: Cat LD50 subcutaneous $8 \mathrm{~g} / \mathrm{kg}$, Guinea pig LD50 intraperitoneal $15 \mathrm{~g} / \mathrm{kg}$, Human TDLo intravenous $714 \mu \mathrm{g} / \mathrm{kg}$, Human TDLo oral $43 \mathrm{mg} / \mathrm{kg}$, Man TDLo oral 3,571 $\mu \mathrm{g} / \mathrm{kg}$, Mouse LD50 intraperitoneal $3800 \mathrm{mg} / \mathrm{kg}$, Mouse LD50 intravenous $30 \mathrm{~g} / \mathrm{kg}$, Mouse LD50 oral $11,400 \mathrm{mg} / \mathrm{kg}$, Mouse LD50 subcutaneous $8,200 \mathrm{mg} / \mathrm{kg}$, Rat LD50 intraperitoneal 4,253 $\mathrm{mg} / \mathrm{kg}$, Rat LD50 intravenous 3,300 mg/kg, Rat LD50 oral 16,600 mg/kg, Rat LD50 subcutaneous $5,580 \mathrm{mg} / \mathrm{kg}$, Women TDLo oral $50 \mathrm{mg} / \mathrm{kg}$.

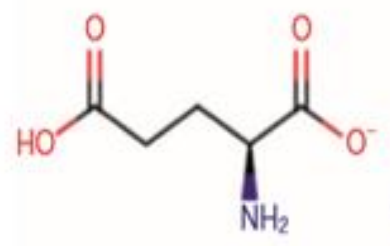

(a)

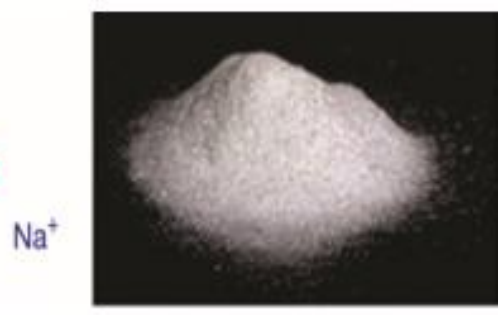

(b)

Fig (1): a- Structure of MSG, b- shape of MSG

\section{MONOSODIUM GLUTAMATE (MSG)...THE DISCOVERY}

In 1866, a German chemist (Karl Heinrich Ritthausen) who treated wheat gluten discovered Glutamic acid [14]. In the year 1908, (Kikunae Ikeda) isolated glutamic acid as a flavoring substance from type of seaweed called Laminaria japonica (kombu) by crystallization and aqueous extraction, and he described its taste as (umami) [15]. (Ikeda) filed a patent for the production of glutamate called "monosodium glutamate (MSG)" after noticing that sodium glutamate was the most palatable to taste and the best solubility among the properties of the salts he studied (such as potassium glutamate, magnesium and calcium), and he also observed that it was easy to crystallize [16]. In 1909, the Suzuki Brothers produced (MSG), calling it ("essence of taste") (Aji-no-moto) [17]. The Japanese described the taste of MSG as (umami), and Westerners described it as meaty or stew-like [18]. To this day, glutamate is still widely consumed in large quantities (frozen meals, canned foods, fast foods, potato chips, etc.) by consumers, despite controversy surrounding the safety of this substance [19].

\section{THE EFFECT OF MSG ON FOOD INTAKE, OBESITY AND BODY IMMUNITY}

Obesity and metabolic syndrome are considered global epidemics that raise public health concern. The immune system also contributes to achieving physical balance and maintaining a balanced metabolic regulation. There was a clear increase in food intake by 100 French men who were given soup and vegetables with MSG added. In addition, it believed that adding MSG to foods causes an increase in fat, magnesium and calcium [20]. In a test of (36) volunteers to study the increase in food intake by adding MSG in different concentrations as a flavoring agent, when the results related to periods of hunger and food intake were measured, the soup containing MSG satisfactory to the volunteers and was more delicious than the MSG-free soup [21].

In another study, it was shown there is a link between increased food intake and hunger and the addition of MSG as a flavor enhancer to the soup, as this was studied on 32 volunteers [22]. In the other hand, we find there are studies linking MSG to nutritional satiety, as it was contrary to other studies [23]. 
Collison et al. (2012) directed the increase in rat bodyweight to the activity of leptin in the visceral adipose tissue, where he injected (19 weeks old) rats with (2 mg / g) MSG [24].

Husarova \& Ostatnikova (2013) Summarized their research there is no relationship between MSG consumption and obesity, and it also has no effects on insulin and blood sugar levels [25].

Miranda Lopez et al. (2015) showed that MSG increases appetite while eating a meal by enhancing the flavor of the food, but at the same time delaying eating by stimulating the satiety center. Also suggested that the increase in obesity in addition to metabolic syndrome might be a result of increased intake of processed foods containing MSG [26].

Ataseven, Yuzbasioglu et al. (2016) showed that there was an increase in chromosomal aberrations and sister chromatid exchanges in human lymphocytes. Thus, MSG may have genotoxic effects on lymphocytes in the peripheral blood of humans [27].

Wafaa M. et al. (2018) demonstrated that giving MSG in low doses caused the male albino rats to gain weight. In addition to changes in brain [28].

Uche Stephen Akataobi (2020) found that in the event of exposure to MSG, it leads to the interruption of the hypothalamic signaling process of leptin, thus an animal with little movement and has the ability to eat more food [29].

\section{THE EFFECT OF MSG ON KIDNEY, LIVER AND HEART}

There are many hypotheses linking kidney and liver diseases with dietary triggers over the years, earlier studies indicated that MSG could be a cause of liver damage because the liver is responsible for removing foreign elements and toxins in the food [30]. Also, histological changes were observed, Bowman's area expanded, in addition to decrease levels of urea and creatinine in the blood, which indicate a decrease in kidney function, when administering doses ranging between (3-6 mg MSG / g of bodyweight) for a period of 45 days to experimental animals [31, 32].

Suzan Muhammad et al. (2020) noted the occurrence of massive destructive changes in heart tissue when high doses of MSG are administered by induction of oxidative stress and atherosclerosis, and indicated that there is an urgent need for further studies to investigate the effect and effects of immediate cessation of MSG consumption. Side effects that extend even after cessation of consumption [33]. Numerous studies have revealed the presence of glutamate receptors in the cardiac tissues of humans, rats and monkeys, not as it was believed to be limited to the nervous system only [34, 35].

On the contrary, Henry-Unaeze (2017) proved that during the consumption of MSG, there was no effect on the pituitary hormones in the blood nor the function of the nervous system, noting that it was safe [36].

Due to the importance of awareness of food additives and their impact on the human body, modern technology has paid attention to this by creating a mobile application that examines the side effects of food additives via the Semantic Web (Duygu Çelik Ertuğrul (2016) by presenting a research project on a safe mobile food consumption system (FoodWiki) as shown in Figure (2), where this developed system checks the ingredients written on the contents label on food boxes in the market, then explains each ingredient and warns consumers about the presence of items that are not suitable for them, such as those suffering from heart diseases, allergies, or An increase in blood levels, etc. [37]. 
As long as there is a life for a person, we find an increasing number of researches concerning his safety and the sustainability of the survival of his healthy genes unaffected by food technology development.

\section{DISCUSSION}

A new program has been prepared to re-evaluate food additives that were permitted by the European Union (EU) before 2009, according to the European Union Regulation No. (2010/257). After assessing the safety of using MSG and other glutamic [38] where the license was given to use MSG as a food additive by the European Union in accordance with the second appendix of the regulation (EC) No. $1333 / 2008$ compounds as food additives which set a maximum use of $10 \mathrm{~g} / \mathrm{kg}$, alone or in combination, expressed as glutamic acid [39], the European Food Safety Authority (EFSA) committee provided its scientific opinion that there are no harmful effects in the short-term studies of the absorption of glutamate in the intestine, as well as in studies of developmental, reproductive, chronic and non-chronic, and the only effect observed was an increase without adverse results in the weight of the spleen and kidneys, and therefore this increase is not considered harmful [38].

While the European Food Safety Authority set in 2017 (30 mg / kg) of body weight, expressed in glutamic acid as the permissible amount per day. EFSA also clarified the quantities that, when used daily, can cause symptoms are insulin increase (> $143 \mathrm{mg} / \mathrm{kg}$ ), symptom complex (> $42.9 \mathrm{mg} / \mathrm{kg}$ ), blood pressure increase $(150 \mathrm{mg} / \mathrm{kg})$ and headache $(85.8 \mathrm{mg} / \mathrm{kg})[40]$.

In view of the contradictions between the European Food Safety Authority statement about the safety of using MSG and the analysis of previous and recent studies that indicate the risks of consuming it, it is better to avoid its consumption or consumption as much as possible by knowing the daily agreed upon dose by the stakeholders.

\section{CONCLUSION}

Given what has been mentioned, there is a clear idea about food additive (monosodium glutamate E621 - MSG), the quantities that are allowed to be eaten per day are (EFSA). Now it is assumed that you know the following:

What is your actual daily consumption of MSG?

What foods contain MSG?

Are you allergic to MSG or one of the food additives?

The simplest way to work is to read food labels on packages before purchasing them. 


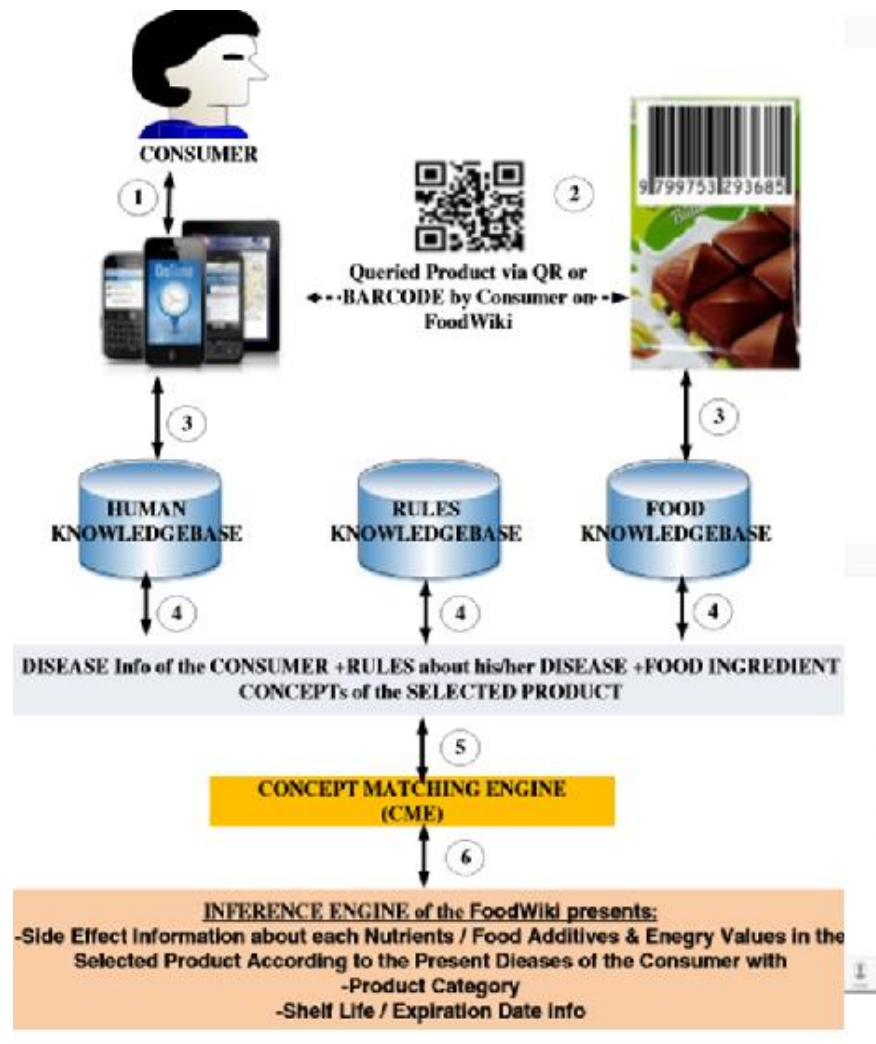

(a)

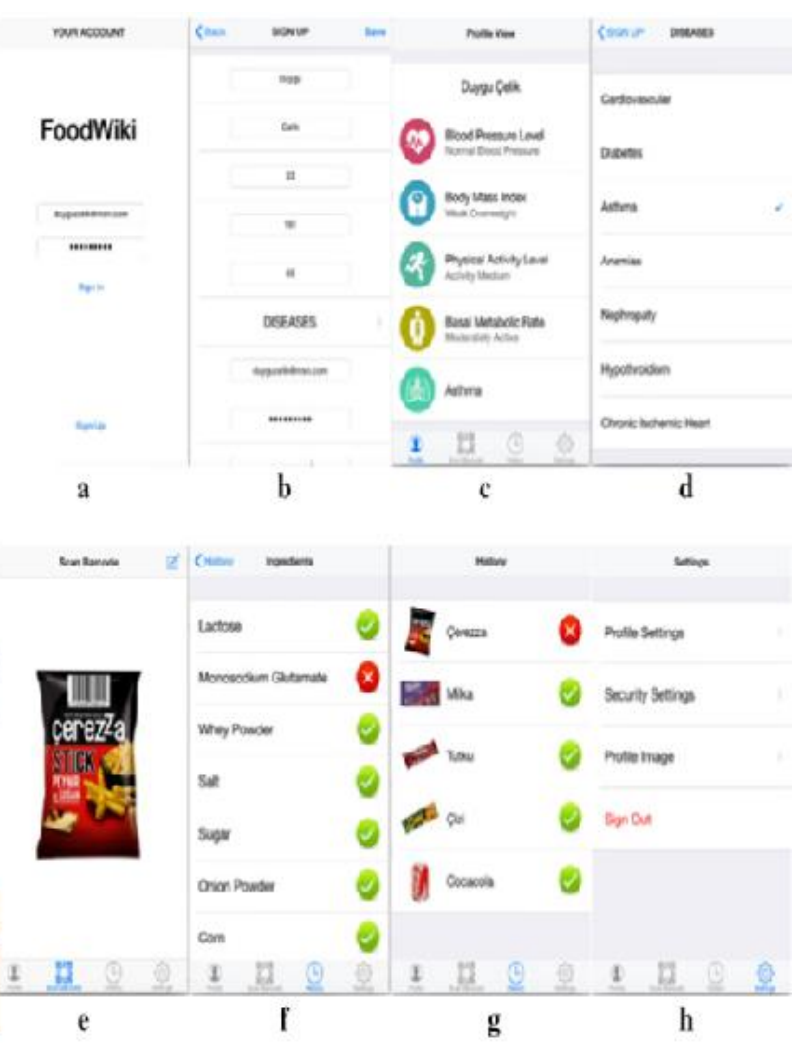

(b)

Fig (2): a- System working mechanism, b- The customer member who has asthma disease, chooses various products, and gets the results on the android mobile application of the system though knowledge base

\section{REFERENCES}

[1] EUFIC (2006) FONDAMENTI 06/2006. Additivi alimentari. European Food Information Council (EUFIC), Brussels. Available www.eufic.org/ article/it/ expid/basics-additivi-alimentari. Accessed 19 Dec 2016.

[2] P. Laganà et al. (2017). Chemistry and Hygiene of Food Additives. Chemistry of Foods, DOI 10.1007/978-3-319-57042-6_4.

[3] Harris, J.B. (1986). Natural toxins. Animal, plant and microbial. Cited in food and additives in tolerance in childhood P. 179. Black well scientific London -Boston.

[4] Lindsay, R.C. (1985). Food additives in fennema. cited in: Food additives intolerance in child hood. P.179.Ed. David, T.J. Blackwell scientific. London-Boston.

[5] Gerhard Heinemeyer, Matti Jantunen, Pertti Hakkinen (2019). The Practice of Consumer Exposure Assessment. Springer International Publishing. 10.1007/978-3-319-96148-4.

[6] Paula Neto HA, Ausina P, Gomez LS, Leandro JGB, Zancan P and Sola-Penna M (2017). Effects of Food Additives on Immune Cells As Contributors to Body Weight Gain and ImmuneMediated Metabolic Dysregulation. Front. Immunol. 8:1478. doi: 10.3389/fimmu.2017.01478.

[7] Dar HY, Shivani C, Karishma S, Azam Z, Anupam R, et al. (2017). Immunomodu latory Effects of Food Additives. Int J Immunother Cancer Res 3(1): 019-031. DOI: http://doi.org/10.17352/2455-8591.000015 
[8] Steven A, Porcelli T, Gary Firestein, Ralph Budd, Sherine E, et al. (2013). Lymphocytes Kelley's textbook of Rheumatology, 9th edition, Chapter 18:255267. Link: https://goo.gl/Kytzru

[9] Zeratsky, K. R. D. Answers from Katherine Zeratsky, R. D., L. D. Mayo (2016). Foundation for Medical Education and Research. www.mayoclinic.org/expert-biographies/katherinezeratsky-r-d-l-d/bio-20025123

[10] O’Neil, M. J. (2001). In The Merck Index - An Encyclopedia of Chemicals, Drugs, and Biologicals 13th Edn (Whitehouse Station, USA).

[11] Budavari, S. (1989). In The Merck Index - Encyclopedia of Chemicals, Drugs and Biologicals (Merck and Co., USA).

[12] Rim, K. (2017). Toxicological evaluation of MSG for the manufacturing workers' health: A literature review. Toxicol. Environ. Health Sci. 9, 1-11 https://doi.org/10.1007/s13530017-0297-1

[13] Arezoo Campbell (2014). Monosodium Glutamate (MSG). Encyclopedia of Toxicology, Elsevier Reference Collection in Biomedical Sciences• 3rd Edition - Pages 391-392. https://doi.org/10.1016/B978-0-12-386454-3.00040-3

[14] Plimmer, R. H. A. (2012). In The Chemical Constitution of the Protein 2nd Edn (eds R. H. A. Plimmer and F. G. Hopkins) 114 (Longmans, Green and Co., United State).

[15] Lindemann, B., Ogiwara, Y. \& Ninomiya, Y. (2002). The discovery of umami. Chemical Senses 27, 843-844.

[16] Ikeda, K. (1908). A production method of seasoning mainly consists of salt of L-glutamic acid. Japanese Patent 14804.

[17] Chiaki, S. (2009). History of glutamate production. Am. J. Clin. Nutr. 90, 728S-732S.

[18] Fuke, S. \& Shimizu, T. (1993). Sensory and preference aspects of umami. Trends Food Sci. Technol. 4, 246-251.

[19] Shrestha S, Jha C, Das BL, Yadav P. (2018). Effects of monosodium glutamate on liver tissue of wistar albino rats - a histological and biochemical study. Exp Anim 8:10.

[20] Bellisle, F., Monneuse, M. O., Chabert, M., Larue-Achagiotis, C., Lanteaume, M. T., \& LouisSylvestre, J. (1991). Monosodium glutamate as a palatability enhancer in the European diet. Physiology \& behavior, 49(5), 869-873.

[21] Rogers, P. J., \& Blundell, J. E. (1990). Umami and appetite: effects of monosodium glutamate on hunger and food intake in human subjects. Physiology \& behavior,48(6),801-804.

[22] Yeomans, M. R., Gould, N. J., Mobini, S., \& Prescott, J. (2008). Acquired flavor acceptance and intake facilitated by monosodium glutamate in humans. Physiology \& behavior, 93(4), 958966.

[23] Masic U, \& Yeomans MR (2014b). Umami flavor enhances appetite but also increases satiety. The American Journal of Clinical Nutrition, 100(2), 532-538. doi: ajen.113.080929 [pii] 10.3945/ajcn. 113.080929 [PubMed: 24944058].

[24] Collison KS, Makhoul NJ, Zaidi MZ, Al-Rabiah R, Inglis A, Andres BL, et al. (2012). Interactive effects of neonatal exposure to monosodium glutamate and aspartame on glucose homeostasis. Nutr Metab (Lond); 9:58.

[25] Husarova V, \& Ostatnikova D (2013). Monosodium glutamate toxic effects and their implications for human intake: a review. The Journal of Medical Research, 1-12. doi: $10.5171 / 2013.608765$.

[26] López-Miranda V, Soto-Montenegro M, Uranga-Ocio J, Vera G, Herradón E, González C, Blas C, Martínez-Villaluenga M, LópezPerez A, Desco M. (2015). Effects of chronic dietary exposure to monosodium glutamate on feeding behavior, adiposity, gastrointestinal 
motility, and cardiovascular function in healthy adult rats. Neurogastroenterol Motil 27:1559-1570.

[27] Ataseven N, Yuzbasioglu D, Keskin AC, \& Unal F (2016). Genotoxicity of monosodium glutamate. Food and Chemical Toxicology, 91, 8-18. doi: 10.1016/j.fct.2016.02.021 [PubMed: 26929995].

[28] Abdel Moneim, W.M., Yassa, H.A., Makboul, R.A. et al. (2018). Monosodium glutamate affects cognitive functions in male albino rats. Egypt $\mathrm{J}$ Forensic Sci 8, 9. https://doi.org/10.1186/s41935-018-0038-x

[29] Akataobi US. (2020). Effect of monosodium glutamate (MSG) on behavior, body and brain weights of exposed rats. Environ 5is; http://www.environmentmed.org/text.asp?2020/5/1/3/283007

[30] Tawfik MS, Al-Badr N. (2012). Adverse effects of monosodium glutamate on liver and kidney functions in adult rats and potential protective effect of vitamins C and E. Food Nutr Sci 3:651.

[31] Elbassuoni, E. A., Ragy, M. M., \& Ahmed, S. M. (2018). Evidence of the protective effect of L arginine and vitamin D against monosodium glutamate-induced liver and kidney dysfunction in rats. Biomedicine and Pharmacotherapy.108, 799-808.

[32] Sharma, A. (2015). Monosodium glutamate-induced oxidative kidney damage and possible mechanisms: A mini-review. Journal of Biomedical Science. 22:93, 1-6.

[33] Hazzaa, S.M., El-Roghy, E.S., Abd Eldaim, M.A. et al. (2020). Monosodium glutamate induces cardiac toxicity via oxidative stress, fibrosis, and P53 proapoptotic protein expression in rats. Environ Sci Pollut Res 27, 20014-20024. https://doi.org/10.1007/s11356-020-08436-6

[34] Dumas SJ, Bru-Mercier G, Courboulin A, Quatredeniers M, RuckerMartin C, Antigny F, Nakhleh MK, Ranchoux B, Gouadon E, Vinhas M-C (2018). NMDA-type glutamate receptor activation promotes vascular remodeling and pulmonary arterial hypertension. Circulation 137:2371-2389.

[35] Gill SS, Pulido OM (2001) Glutamate receptors in peripheral tissues: current knowledge, future research, andimplicationsfor toxicology. Toxicol Pathol 29:208 -223.

[36] Henry-Unaeze HN (2017). Update on food safety of monosodium L-glutamate (MSG). Pathophysiology, 24(4), 243-249. doi: S0928-4680(17)30072-X[pii] 10.1016 /j. pathophys. 2017.08.001 [PubMed: 28943112].

[37] Celik Ertuğrul, Duygu (2016). FoodWiki: A Mobile App Examines Side Effects of Food Additives Via Semantic Web. Journal of Medical Systems, 40(2). DOI 10.1007/s10916015-0372-6

[38] Ec. (2020). Call for technical data on the permitted food additives glutamic acid (E620), monosodium glutamate (E 621), monopotassium glutamate (E 622), calcium diglutamate (E 623), monoammonium glutamate (E 624) and magnesium diglutamate (E 625).

https://ec.europa.eu/food/sites/food/files/safety/docs/fs_food-improvement-e620625_glutamates_201904113_e422_data.pdf

[39] Eur-lex. (2013). Annex II to Regulation (EC) No 1333/2008 is replaced by the text of the Annex to this Regulation. content/EN/TXT/?uri=CELEX:02011R1129-20131121 https://eur-lex.europa.eu/legal-

[40] Efsa, (2017). Re-evaluation of glutamic acid (E 620), sodium glutamate (E 621), potassium glutamate (E 622), calcium glutamate (E 623), ammonium glutamate (E 624) and magnesium glutamate (E 625) as food additives. EFSA. DOI:10 .29 03 /j.efsa .2017.4910. https://www.efsa.europa.eu/en/efsajournal/pub/4910 